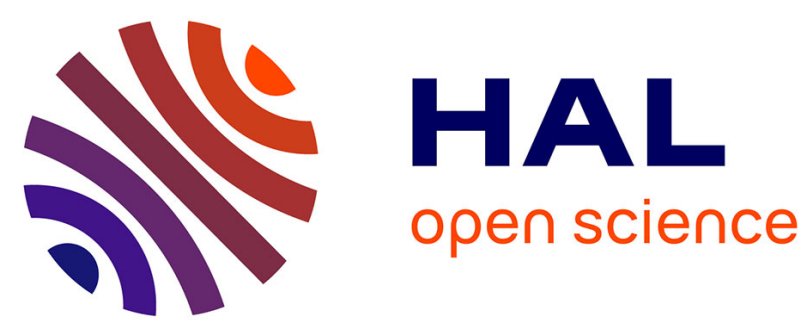

\title{
Screening for Leptospira DNA in blood and urine from 30 apparently healthy dogs
}

I. Goy-Thollot, Z. Djelouadji, M. Nennig, G. Hazart, M. Hugonnard

\section{To cite this version:}

I. Goy-Thollot, Z. Djelouadji, M. Nennig, G. Hazart, M. Hugonnard. Screening for Leptospira DNA in blood and urine from 30 apparently healthy dogs. Revue Vétérinaire Clinique, 2018, 10.1016/j.anicom.2018.06.003 . hal-01840573

\section{HAL Id: hal-01840573 https://hal.science/hal-01840573}

Submitted on 16 Jul 2018

HAL is a multi-disciplinary open access archive for the deposit and dissemination of scientific research documents, whether they are published or not. The documents may come from teaching and research institutions in France or abroad, or from public or private research centers.
L'archive ouverte pluridisciplinaire HAL, est destinée au dépôt et à la diffusion de documents scientifiques de niveau recherche, publiés ou non, émanant des établissements d'enseignement et de recherche français ou étrangers, des laboratoires publics ou privés. 


\section{Screening for Leptospira DNA in blood and urine from 30 apparently healthy dogs}

Recherche d'ADN de leptospires pathogènes dans le sang et l'urine de 30 chiens apparemment sains 这

\section{I.Goy-Thollotab ${ }^{\text {ab }}$ Z.Djelouadjicd ${ }^{\text {cd }}$.Nennig ${ }^{\mathrm{e}}$ G.Hazart $^{\mathrm{e}}$ M.Hugonnard ${ }^{\text {de }}$}

a Clinic for Small Animal Emergency and Intensive Care Unit, Veterinary Campus of Lyon, VetAgro Sup, University of Lyon, 69280 Marcy L'Étoile, France

b EA 4174, 'Sepsis, Inflammation and Haemostasis', Veterinary Campus of Lyon, VetAgro Sup, University of Lyon, 69280 Marcy L’Étoile, France

c Public Health Unit, Veterinary Campus of Lyon, VetAgro Sup, University of Lyon, 69280 Marcy L'Étoile, France

d $\quad$ USC 1233, 'Équipe de recherche sur la Leptospirose', Veterinary Campus of Lyon, VetAgro Sup, University of Lyon, 69280 Marcy L'Étoile, France

e $\quad$ Clinic for Small Animal Internal Medicine, Veterinary Campus of Lyon, VetAgro Sup, University of Lyon, 69280 Marcy L'Étoile, France

https://doi.org/10.1016/i.anicom.2018.06.003

Summary

Asymptomatic carriage of leptospires in dogs has not been extensively studied. A prospective study was conducted on thirty apparently healthy male dogs to screen for Leptospiral DNA in their blood and urine. All dogs were up to date with a bivalent vaccine against Leptospirosis. Microscopic agglutination test (MAT) and real-time PCR analysis in blood and urine were performed for each dog. Six of 30 (20\%) dogs had positive PCR results: two from blood samples (all MAT titres $\leq 160$ ) and four from urine samples (one with maximal MAT titres of 2560 and three with all MAT titres $\leq 160$ ). Ten months later, PCR analyses of blood and urine were repeated for these six dogs. Four had negative PCR results from blood and urine. The other two, with positive urine results at the first sampling, had negative PCR results from urine and positive PCR results from blood. In this study, the urinary shedding of leptospires appeared to be transient. As shown previously, serological status was not correlated with PCR results. Low but detectable amounts of Leptospiral DNA in the blood of some apparently healthy dogs raises questions regarding the pathophysiology of Leptospirosis and the diagnostic consequences of high-sensitivity PCR assays.

\section{Résumé}

Le portage asymptomatique des leptospires chez le chien est encore mal connu. Une étude prospective sur 30 chiens mâles apparemment sains a recherché la présence 
d'ADN de leptospires pathogènes dans leur sang et leur urine. Chaque chien était à jour de ses vaccins contre la leptospirose (vaccins inactivés bivalents sur tous les chiens). Une sérologie par technique de microagglutination (MAT) et une PCR en temps réel sur l'urine et le sang ont été réalisées pour chaque chien. Six chiens sur 30 $(20 \%)$ avaient des résultats PCR positifs : deux chiens sur sang (titres MAT $\leq 160$ pour ces deux chiens), quatre chiens sur urine (titre MAT maximal de 2560 pour un chien, titres MAT $\leq 160$ pour les trois autres). Dix mois plus tard, les analyses PCR ont été répétées pour les six chiens avec un résultat positif. Quatre chiens avaient des résultats négatifs sur sang et urines. Deux chiens, qui avaient initialement une PCR positive sur urines, avaient une PCR positive sur sang et négative sur urines. Dans cette étude, l'excrétion urinaire des leptospires apparaissait discontinue. Comme dans d'autres études, les profils sérologiques n'étaient pas corrélés aux résultats PCR. Trouver dans le sang de chiens apparemment sains des quantités faibles mais détectables d'ADN de leptospires interroge sur la physiopathologie de la leptospirose et les conséquences diagnostiques de tests PCR très sensibles.

Keywords

Dog

Leptospirosis

PCR

Urine

Blood

Mots clés

Chien

Leptospirose

PCR

Urine

Sang

\section{INTRODUCTION}

Leptospirosis is a re-emerging worldwide zoonotic disease caused by spirochetes that can affect many domestic mammals, including dogs. Humans and dogs are both susceptible species and represent incidental hosts who can develop similar severe acute forms of the disease. Many wild rodents are maintenance hosts for leptospires. They chronically shed the spirochetes from their renal tubules into their urine without expressing any symptoms [1]. The renal carriage of leptospires that is associated with high-intensity, constant and long-term Leptospiruria is characteristic of maintenance 
hosts [2]. Dogs are the maintenance host for the Canicola serovar and an incidental host for other serovars [1]. Canine Leptospirosisvaccines are reported to provide longterm protection not only against infection but also against the renal carrier state for the vaccine-targeted serogroups [3], [4], [5], [6]. Leptospiruria in incidental hosts is considered a transient, intermittent and low-intensity condition [2], [7]. The asymptomatic carriage of leptospires in canines has not been extensively studied. However, many studies have demonstrated that apparently healthy dogs can have high microscopic agglutination test (MAT) titres for different serogroups, indicating that exposure to Leptospira spp. is common in dogs [8], [9], [10]. Some studies have investigated the prevalence of urinary shedding of leptospires based on PCR analyses in apparently healthy dogs or in a general referral hospital population. The percentage of positive samples has been reported to vary between 1.5 and $20 \%$ [11], [12], [13], [14], [15]. In those studies, the renal carrier state was evaluated at a single point in time and the vaccination status was not specifically addressed in two of the studies [12], [15]. The aim of the current study was to screen for Leptospira DNA in urine and blood samples from 30 apparently healthy, privately owned dogs with a well-known vaccination history and behavioural habits that favoured contamination and to recheck those with a positive result (if any) on a second occasion, without administering a course of antibiotics in between tests.

\section{MATERIALS AND METHODS}

\subsection{Selection of the population}

Thirty apparently healthy student-owned dogs from a veterinary university were included. The ethical committee of the University approved this study. Recruitment of the population was made on a voluntary basis in June 2011. The study population was selected based on answers to a questionnaire. Male dogs with a lifestyle that favoured exposure to Leptospirosis were eligible for inclusion. The risk of exposure was assessed based on the frequency of walks near water sources and/or bathing in these water sources during the past two months.

\subsection{Vaccination status}

Vaccination histories (date and type of vaccine), which were obtained from valid vaccination certificates, were recorded for each dog.

\subsection{Epidemiological data}

The data recorded for each dog included living place; lifestyle (number of dogs in the household and the main source of activity: work dog, hunting dog, breeder or pet); 
walking, bathing and drinking habits (ditchwater, running water, lake, swamp, pond or tap water exclusively); and proximity to wild rodents, which was estimated by the owner.

\subsection{Clinical status evaluation}

A thorough medical history was recorded, and each dog underwent a complete physical examination, including a urinary dipstick (Combur 10 Test, Roche) test and specific gravity measurements using refractometer (URC-Ne, Atago). Only apparently healthy dogs were included in the study. Glucosuria was not an exclusion criterion.

\subsection{Sample collection and DNA isolation}

The owners collected urine via the free-catch method in a sterile plastic urine cup during the dog's first morning walk. Subsequently, one millilitre of urine was placed in a dry tube for PCR analysis. Two blood samples were collected at the University Hospital on the same day as the urine sampling: one in a clot tube for MAT serology and the other in a tube containing EDTA for PCR analysis. The urine samples were centrifuged at $3500 \mathrm{~g}$ for $10 \mathrm{~min}$ prior to DNA extraction to obtain $200 \mu \mathrm{L}$ of pellet. DNA was isolated (QIAamp DNA Mini Kit, Qiagen, Courtaboeuf, France) from $200 \mu \mathrm{L}$ of blood and the urine pellet within hours of sampling, following the manufacturer's instructions. The DNA template was stored at $-20^{\circ} \mathrm{C}$.

\subsection{PCR assay on blood and urine}

A public laboratory 1 completed the real-time PCR analysis. Blood and urine were handled separately, and the assays were completed using a kit (Taqvet Pathogenic Leptospira Real-Time PCR kit (LEPT/50), LSI, Lissieu, France). The Taqvet kit included a specific internal control to check for PCR inhibitors. Each run included a no template control, a positive control using a reference laboratory strain (L. interrogans Icterohaemorrhagiae strain 9120) as a template and a negative control (PCR mix without the targeted DNA). The no template control was defined as a negative control that undergoes all the process including extraction of nucleic acids.

A final volume of $25 \mu \mathrm{L}$, which consisted of $20 \mu \mathrm{L}$ lepto mix (LSI) and $5 \mu \mathrm{L}$ of the targeted DNA, was analysed via PCR using a Rotor-Gene $Q$ system (Qiagen) using the following program: 10 min of enzyme activation at $95^{\circ} \mathrm{C}$, followed by 45 cycles of $95^{\circ} \mathrm{C}$ for $15 \mathrm{~s}$ and $60^{\circ} \mathrm{C}$ for $1 \mathrm{~min}$ The detection threshold was $10^{3}$ leptospires $/ \mathrm{mL}$ of blood or urine. Each PCR was performed in duplicate to assess the reproducibility of the results. All samples have been tested in the same run. 


\subsection{Genotyping}

The 16S rRNA gene was amplified with the primers LeptA (5'GGCGGCGCGTCTTAAACATG-3') and LeptB (5'-TTCCCCCCATTGAGCAAGATT$\left.3^{\prime}\right)$ [16]. The amplified fragments were sequenced (see appendix), and the sequences were compared to $16 S$ rRNA sequences available in Genbank? . Further characterization was performed using the multispacer sequence typing (MST) method with MST1, MST3 and MST9 primers as described by Zilber et al. [17]. For one dog (dog №19), a variable-number tandem-repeat (VNTR) analysis was subsequently performed as an alternative molecular approach [18].

\subsection{Serologic examination}

Microscopic agglutination tests were performed by a public laboratory for 19 serovars (Australis, Bratislava, Munchen, Autumnalis, Bim, Canicola, Grippotyphosa, Vanderhoedoni, Icterohaemorrhagiae, Copenhageni, Panama, Mangus, Pomona, Mozdok, Pyrogenes, Sejroe, Saxkoebing, Hardjo, and Wolfii) representing nine serogroups (Australis, Autumnalis, Canicola, Grippotyphosa, Icterohaemorrhagiae, Panama, Pomona, Pyrogenes and Sejroe). The initial dilution used was 1/40.

\subsection{Follow up}

Owners were individually informed of the MAT and PCR results. For dogs that had positive PCR results on the initial test, informed consent of the pet owner was required to recheck the blood and urine ten months later using the same PCR method. The vaccination schedule was continued unchanged. All dogs with at least one positive PCR result either the first or second test were treated with doxycycline $(5 \mathrm{mg} / \mathrm{kg} \mathrm{BID \text {, }}$ 14 days) following the second sampling of blood and urine.

\section{RESULTS}

The study included 30 male dogs, 14 of which were neutered (47\%). In total, two dogs $(6 \%)$ were small breeds $(<10 \mathrm{~kg}), 20(67 \%)$ were medium breeds (between 10 and $30 \mathrm{~kg}$ ), and eight (27\%) were large breeds (> $30 \mathrm{~kg}$ ), including eight mixed-breed dogs, four Border Collies, four Australian Shepherds, two Samoyeds, two Labradors, two Golden Retrievers, one flat-coated Retriever, one Entlebuch Mountain Cattle dog, one Collie, one Brittany Spaniel, one Long-Haired Pyrenean Sheepdog, one Beagle, one Bernese Mountain dog and one Manchester Terrier. The age of the dogs varied from eight months to 14.5 years, and the median age was 26.5 months (8-177 months). All dogs primarily lived in suburban areas and had access to one or more water sources during walks. They also had access to the Veterinary Campus and its surrounding areas, which contain many sources of stagnant water (especially ponds, puddles and ruts) and is adjacent to areas where dairy cows and wild rodents lived. Certain dogs 
also had access to lakes and/or running water (rivers, streams and springs) outside the Veterinary Campus area. During the 15 days preceding the first sampling, 20 (67\%) dogs went for a swim, and all dogs drank from a natural water source.

Less than one year before the first sampling, all dogs had received a booster vaccine or completed a primo-vaccination against Leptospirosis with a two-serovar inactivated vaccine, including the Canicola and Icterohaemorrhagiae serovars (25 EURICAN LR (Merial), two CANIGEN L (Virbac), two ENDURACELL LR (Zoetis), one NOBIVAC L (MSD)) (Table 1). 
Table 1. Summary table of vaccinal, serological and PCR data.

$$
\text { MAT serology }
$$

\begin{tabular}{|c|c|c|c|c|c|c|c|c|c|c|c|c|c|c|c|c|c|c|}
\hline $\begin{array}{c}N^{\circ} \text { of } \\
\operatorname{dog}^{\circ}\end{array}$ & 19 & COP & MUN & AUS & BRAT & AKI & BIM & CAN & GRIP & VAN & PAN & MAN & POM & MOZ & PYR & SJ $\quad$ SAX & WOLF & Last booste \\
\hline
\end{tabular}

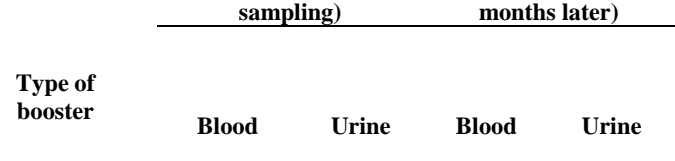

\begin{tabular}{|c|c|c|c|c|c|c|c|c|c|c|c|c|c|c|c|c|c|c|c|c|c|}
\hline 1 & 80 & 320 & 40 & 40 & 80 & & & 2560 & & & & 40 & & & 160 & $<3$ months & EURICAN LR & Negative & Negative & & \\
\hline 2 & 640 & 1280 & 2560 & 1280 & 1280 & 320 & 320 & 2560 & 40 & 40 & 1280 & 2560 & & & & $<3$ months & EURICAN LR & Negative & Positive & Negative & Negative \\
\hline 3 & 320 & 640 & 640 & 40 & 160 & & & 640 & 1280 & 320 & & 1280 & 80 & 40 & 40 & $<3$ months & EURICAN LR & Negative & Negative & & \\
\hline 4 & 640 & 1280 & 40 & & 1280 & & & 640 & & & & & & & 320 & $<3$ months & EURICAN LR & Negative & Negative & & \\
\hline 5 & 80 & 640 & 40 & & 40 & & & 640 & & & & & & & & $<3$ months & EURICAN LR & Negative & Negative & & \\
\hline 6 & 40 & 40 & & & & & & 80 & & & & & & & & 3-6 months & EURICAN LR & Negative & Negative & & \\
\hline 7 & & & & & & & & 1280 & & & & & & & & 3-6 months & EURICAN LR & Negative & Negative & & \\
\hline 8 & 80 & 80 & & & 40 & 40 & 80 & 80 & & & & & & & & 3-6 months & ENDURACELL & Positive & Negative & Negative & Negative \\
\hline 9 & 40 & 40 & & & 40 & & & 80 & & & & & & & 80 & 3-6 months & EURICAN LR & Negative & Negative & & \\
\hline 10 & 80 & 80 & & & & & & 160 & & & & & & & & $3-6$ months & EURICAN LR & Negative & Negative & & \\
\hline 11 & 40 & 40 & & & & & & & & & & & & & & $3-6$ months & EURICAN LR & Negative & Negative & & \\
\hline 12 & 40 & 40 & 40 & & 40 & & & & & & & & & & & $3-6$ months & EURICAN LR & Negative & Negative & & \\
\hline 13 & 40 & 40 & & & & 40 & 40 & 160 & & & & & & & & 3-6 months & $\begin{array}{l}\text { ENDURACELL } \\
\text { LR }\end{array}$ & Negative & Positive & Negative & Negative \\
\hline 14 & 40 & 80 & 40 & 40 & 40 & & & 640 & & & & & & & & 3-6 months & EURICAN LR & Negative & Negative & & \\
\hline 15 & 80 & 160 & & & & 40 & 80 & 80 & & & & & & & & 6-9 months & EURICAN LR & Negative & Negative & & \\
\hline 16 & 160 & 320 & 40 & & 40 & & & 160 & & & & & & & & 6-9 months & EURICAN LR & Negative & Negative & & \\
\hline 17 & 40 & 40 & & & 40 & & & 80 & & & & & & & & 6-9 months & EURICAN LR & Negative & Negative & & \\
\hline 18 & 80 & 80 & & & & & & 160 & & & & & & & & 6-9 months & EURICAN LR & Positive & Negative & Negative & Negative \\
\hline 19 & 40 & 80 & 40 & & 40 & & & 80 & & & & & & & & 6-9 months & EURICAN LR & Negative & Positive & Positive & Negative \\
\hline 20 & 40 & 40 & 40 & & 40 & & & & & & & & & & & 6-9 months & EURICAN LR & Negative & Negative & & \\
\hline 21 & 80 & 160 & 40 & & 40 & 40 & 40 & 160 & & & & & & & 80 & 6-9 months & EURICAN LR & Negative & Negative & & \\
\hline 22 & & & & & & & & & & & & & & & 80 & 6-9 months & NOBIVAC L & Negative & Negative & & \\
\hline 23 & 80 & 80 & & & 80 & & & & 160 & 160 & & & 40 & 40 & & 6-9 months & EURICAN LR & Negative & Positive & Positive & Negative \\
\hline 24 & 80 & 80 & & & 40 & 40 & 80 & 2560 & & & & & 40 & 40 & 160 & 6-9 months & EURICAN LR & Negative & Negative & & \\
\hline 25 & 160 & 320 & & & & & & 640 & 640 & 160 & & & & 80 & 40 & 6-9 months & EURICAN LR & Negative & Negative & & \\
\hline 26 & 80 & 160 & 40 & & 80 & & & 80 & & & & & & & 80 & $9-12$ months & EURICAN LR & Negative & Negative & & \\
\hline 27 & 80 & 40 & 40 & & 40 & & & 40 & & & & & & & & $9-12$ months & EURICAN LR & Negative & Negative & & \\
\hline 28 & 160 & 80 & 80 & & 40 & & & 160 & 40 & & & & & & & $9-12$ months & EURICAN LR & Negative & Negative & & \\
\hline 29 & 640 & 640 & 1280 & 1280 & 640 & 640 & 1280 & & & & & 80 & & & & $9-12$ months & CANIGEN L & Negative & Negative & & \\
\hline 30 & 40 & 40 & 40 & 40 & 40 & & & & & & & & & & 40 & $9-12$ months & CANIGEN L & Negative & Negative & & \\
\hline
\end{tabular}

Abbreviations of serovars: 19: Icterohaemorrhagiae; COP: Copenhageni (serogroup Icterohaemorrhagiae); MUN: Munchen; AUS: Australis, BRAT: Bratislava (serogroup Australis); AKI: Autumnalis; BIM: Bim (serogroup Autumnalis); CAN: Canicola (serogroup Canicola); GRIP: Grippotyphosa; VAN: Vanderhoedoni (serogroup Grippotyphosa); PAN: Panama; MAN: Mangus (serogroup Panama); POM: Pomona; MOZ: Mozdok (serogroup Pomona); PYR: Pyrogenes (serogroup Pyrogenes); SJ: Sejroe; SAX: Saxkoebing; HJ: Hardjo; WOLF: Wolfii (serogroup Sejro). 
No dog had history of renal and/or hepatic diseases. Clinical examinations were normal for all dogs. Urine specific gravity varied between 1.012 and 1.050. In total, one dog (dog №23) had glucosuria without clinical symptoms. Glycaemia was normal $(4.5 \mathrm{mmol} / \mathrm{L}, 0.8 \mathrm{~g} / \mathrm{L})$ for this dog (Accu-Chek Active, Roche). In total, 19 dogs $(63 \%)$ had proteinuria (one + for 17 dogs and two + for two dogs), with urine specific gravities $>1.035$ in 15/19 of these dogs. All dogs except one (dog №2) had hypersthenuric urine. For dog №2, uraemia and creatinaemia were subsequently checked and were within the reference ranges (urea $=6.4 \quad[2-$ $7 \mathrm{mmol} / \mathrm{L}]$; creatinine $=102[60-135 \mu \mathrm{mol} / \mathrm{L}]$ ).

Serological and PCR data are presented in Table 1.

Six out of $30(20 \%)$ dogs had a unique positive PCR result at the first sampling (two from blood, four from urine). At the recheck ten months later, four of those six dogs had negative PCR results for both their blood and urine samples, and two had a unique positive PCR result for their blood sample. These last two dogs had both positive PCR results for their urine at the first sampling. The detailed results are described below. At the first sampling, twenty-four dogs $(80 \%)$ had negative PCR results for both their blood and urine samples. Among them, $15(62.5 \%)$ had MAT titres that were all $\leq 160$, and five $(20.8 \%)$ had MAT titres $\geq 640$ for the vaccinal serogroups only (1/640 for Canicola for one dog, 1/1280 for Canicola for one dog, 1/2560 for Canicola for two dogs and $1 / 640$ for Canicola and Icterohaemorrhagiae for one dog). Two of these five dogs (dog № 1 with a titre of $1 / 2560$ for Canicola and dog № 5 with a titre of 1/640 for Canicola and Icterohaemorrhagiae) had received their last booster less than three months prior to the study. Four dogs (16.6\%) had multiple titres $\geq 640$ for at least one non-vaccinal serogroup (1/1280 for Panama and Grippotyphosa and 1/640 for Australis for one dog, 1/1280 for Australis and Autumnalis for one dog, 1/1280 for Australis for one dog and 1/640 for Grippotyphosa for one dog).

At the first sampling, four dogs (13.3\%) (dogs № 2, 13, 19 and 23) had positive PCR results for their urine samples (cycle threshold $(\mathrm{Ct})=35.62,37.07,38.11$ and 40.0, respectively) and negative PCR results for their blood samples. One dog had glucosuria without hyperglycaemia (dog №23). One out of four dogs (dog №2) had multiple MAT titres $\geq 640$ (1/2560 for Panama, Australis and Canicola; 1/1280 for Icterohaemorrhagiae). The other three dogs, including the dog with glycosuria (dog № 23), had MAT titres that were all $\leq 160$. The $16 S$ rRNA gene amplification results indicate that all the sequences were similar and that the genomospecies found in these four dogs was $L$. interrogans. Further molecular characterization via MST failed because an insufficient amount of DNA was available. Ten months later, PCR results for both blood and urine samples were negative for two dogs (dogs № 2 and 13). For the other two (dogs № 19 and 23), PCR results were negative from urine and positive 
from blood samples $(\mathrm{Ct}=30.20$ for dog $\mathrm{N} \circ 19, \mathrm{Ct}=32.64$ for dog $\mathrm{N} \circ 23)$. The $16 \mathrm{~S}$ rRNAgene amplification results indicate that the genomospecies was $L$. interrogans. Further molecular characterization via MST for these two dogs failed. For dog $\mathrm{N} \circ 19$, who had the most substantial Leptospiral DNA burden, another molecular typing method (variable-number tandem-repeat analysis) was completed, and the $L$. interrogansGrippotyphosa Valbuzzi genotype (results for VNTR locus 4, 7, 10: 2, 1, 1, respectively) was identified [18].

At the first sampling, two dogs (6.7\%) (dogs № 8 and 18) had positive PCR results for their blood samples ( $\mathrm{Ct}=34.55$ for $\operatorname{dog} \mathrm{N} \circ 8$ and $\mathrm{Ct}=37.78$ for dog $\mathrm{N} \circ 18$ ) and negative PCR results for their urine samples. For those two dogs, all MAT titres were $\leq 160$. The 16S rRNAgene amplification results indicate that the genomospecies was $L$. borgpetersenii for $\operatorname{dog} N \circ 8$ and $L$. interrogans for dog N 18. Further molecular characterization via MST failed because an insufficient amount of DNA was available. Ten months later, the PCR results for both blood and urine samples were negative for these two dogs.

\section{DISCUSSION}

In this study, 4/30 (13.3\%) vaccinated, apparently healthy, privately owned, male dogs had positive PCR assay results from urine samples. This indicates that asymptomatic urinary shedding of leptospires in male dogs with behavioural habits that favour contamination is not an anecdotal phenomenon, even when the dogs are vaccinated. Overall, $4 / 30$ dogs (13.3\%, 95\% Confidence Interval 5.3-29.6\%) had positive PCR results from urine samples. This frequency is among the highest of those previously reported in asymptomatic dogs: 1.5\% [13], 4.4\% [11], 7\% [15], 8\% 12] and 20\% [14]. However, the small number of dogs in the current study and its design, which favoured the recruitment of urinary shedders, precludes further comparisons of the frequency found in this study with those of previous studies. Indeed, only male dogs were included because they have an increased risk of contamination [19], [20], [21]. The selected dogs were mainly living in suburban areas and had access to one or more water sources during their walks. Living in an urban area, the proximity of outdoor water sources, swimming or drinking from outdoor water sources and indirect exposure to wild rodents have all been suggested to promote Leptospirosis contamination [20], [22].

In our study, all urine samples showing positive PCR results had a quantity of DNA that was notably lower than that reported in the pioneer study describing the MST method [17]. A positive PCR result does not determine whether the pathogen is viable, and the low Leptospiral burden observed here in the urine of apparently healthy dogs is of questionable biological significance. Ideally, cultures would have been 
recommended to investigate this issue. However, this option was rejected because of the difficulties in obtaining positive culture results, even in acute cases with high Leptospiral burdens. The sequencing results showed that there were no false positive results. The diagnostic kits used appeared to be very sensitive, which is a technical advantage. According to the manufacturer's notice for the Taqvet PCR kit, the sample is positive if $\mathrm{Ct}$ values are $<45$. However, a positive test with such a low Leptospiral burden possibly calls into question the biological significance of the results. Limits of detection (LODs) as low as three genome equivalents per $5 \mu \mathrm{L}$ $\left(6 \times 10^{2}\right.$ Leptospires $\left./ \mathrm{mL}\right)$ have been reported for specific real-time PCR assays for detecting Leptospira that have been validated for diagnostic application [23]. Because of this, the positive PCR results observed in this study reflect those obtained under clinical conditions and should be considered in the same regard.

All four dogs with initial positive PCR results for their urine samples had negative PCR results from urine ten months later, without antibiotic treatment. Possible explanations for this include intermittent shedding, natural cleansing or methodological limits due to the detection threshold of the test and the low infectious burden. Surprisingly, two of these dogs had positive results for their blood samples at the recheck.

At the time of the current study, only bivalent inactivated vaccines were available in France. Three of the four dogs with positive PCR results from urine samples were vaccinated with the same vaccine (EURICAN LR, Merial) and one with a different one (ENDURACELL LR, Zoetis). The relative efficiency of vaccines in preventing urinary shedding could not be compared based on the results presented here because of the small size of the study population and because the majority of the study group $(25 / 30)$ was vaccinated with the same vaccine (EURICAN LR, Merial). The genomospecies identified in all four cases was $L$. interrogans. $L$. interrogans contains both pathogenic vaccinal and non-vaccinal serovars associated with canine Leptospirosis. Further genotyping at the serovar level would have been of particular interest here and is absolutely necessary to extend the assessment of vaccination status and renal carrier state. However, the amount of DNA was insufficient for molecular characterization at the serovar level.

In a previous report [12], serologic testing was shown to be a poor predictor of urinary shedding. Three of the four dogs with positive PCR results from urine samples had MAT titres that were all $\leq 160$. One of them was glucosuric, suggesting tubular lesions, possibly caused by leptospires. The dog with a positive PCR result for the urine sample and multiple MAT titres $\geq 640$, including non-vaccinal titres, was the sole dog with isosthenuric urine, but he was not azotemic.

At the population scale, a low prevalence of renal carriage $(\leq 1 \%)$ and a low rate of excretion are expected in incidental hosts, whereas a high prevalence $(\geq 10 \%)$ and a 
high sustained excretion rate are expected in maintenance hosts [2], [24]. Whether dogs can be considered as a maintenance host for serovars other than Canicola has not been determined [11], [25]. A recent publication suggests that, except for Canicola, dogs should be considered as vectors rather than as maintenance hosts [11]. Dogs represent an epidemiological link between the environment, wild fauna and humans, and therefore, they might play a significant role in human contamination in endemic areas [7].

The positive PCR results from blood in four dogs (two at the first sampling and two others at the recheck) were unexpected in France, which is a non-endemic region. The leptospiremic phase has been shown to be short in models susceptible to acute clinical infections and in a rat model of persistent renal colonization [26], [27], [28]. As a consequence, a positive PCR result from blood should correspond to a recent infection. Positive PCR results from blood have been previously reported in Brazil in apparently healthy dogs from a control centre for zoonoses (CCZ) and in dogs living in a neighbourhood with a high prevalence of human leptospirosis with respective frequencies of 7.7 and 14.8\% [14]. The prevalence of Leptospiraemia was higher than that of Leptospiruria in the dogs living in the endemic area for human leptospirosis. Explanations proposed by the authors included a recent outbreak in this area. In our study, which was conducted in a non-endemic area, it seems unlikely that the four positive results obtained from blood were due to recent asymptomatic infections. Nonspecific amplification was also excluded because all positive results obtained with the PCR diagnostic kit were confirmed via sequencing, and the negative controls were valid. Furthermore, for one dog, the L. interrogans Grippotyphosa Valbuzzi genotype was identified using the VNTR method. Vaccination also did not affect the PCR results because a recent vaccination does not interfere with the use of real-time PCR in the diagnosis of canine leptospirosis [29]. The leptospiral burden was low for the four dogs with a positive result for their blood samples, which renders the biological significance of these findings questionable. The amplification of residual DNA from a past infection seems very unlikely as DNA is degraded very quickly. The physiopathological process involved might also be more complex than is commonly thought: recurrent phases of Leptospiraemia in asymptomatic chronic carriers could be a possibility. The fact that two dogs with positive PCR results for their urine at the first sampling had positive PCR results from their blood at the recheck could suggest a complex phenomenon of recurrence. However, evidence for this hypothesis has never been documented, and it requires further investigation.

The limitations of the present study were the small population size, the absence of supporting culture results, the lack of PCR monitoring for the 24 dogs with negative PCR results from blood and urine at first sampling and the failure to genotype the 
Leptospira species identified at the serovar level. It would also have been interesting to test the blood PCR-positive dogs for antibodies a few weeks after the first sample to explore the assumption of a recent infection.

Despite these limitations, this study supports the fact that asymptomatic urinary shedding of leptospires in apparently healthy vaccinated dogs does occur in nonendemic areas and that it may be transient. Whether dogs can be a reservoir for serovars other than Canicola remains controversial. A larger prospective study with close and repeated monitoring of dogs via PCR would be advisable, with a specific effort to determine the serovars involved and to screen for possible associated renal damage. Serological status was found to be a poor predictor of urinary shedding, as has been shown previously [12], [13]. The significance of positive PCR results from blood samples for Leptospiral DNA in dogs from a non-endemic area warrants further investigation. The very low but detectable amounts of Leptospiral DNA in the blood and urine of some apparently healthy dogs raises questions regarding the diagnostic consequences of the extremely high sensitivity of PCR assays. It is also potentially important from a public health point of view. Given the potential veterinary and public health implications of these observations, repeated monitoring in a cohort study would be advisable.

\section{ETHICAL APPROVAL}

All applicable international, national, and/or institutional guidelines for the care and use of animals were followed. All procedures performed in studies involving animals were in accordance with the ethical standards of the institution or practice at which the studies were conducted.

\section{DISCLOSURE OF INTEREST}

The authors declare that they have no competing interest.

\section{ACKNOWLEDGEMENTS}

The authors are grateful to Pr. A. Kodjo (public laboratory) for the free analyses and for the technical support. 


\section{REFERENCES}

$[11$

S. Faine Leptospira and leptospirosis

(second ed.), MediSci, Melbourne (1999)

[2]

Y. Chernukcha, Y. Ananyina, N. Zenkovitch Pathogenicity of Leptospires of various serological types for some species of wild rodents

Zentralbl Bakteriol, 228 (1974), pp. 388-395

[3]

H.L. Klaasen, M.J. Molkenboer, M.P. Vrijenhoek, M.J. Kaashoek Duration of immunity in dogs vaccinated against leptospirosis with a bivalent inactivated vaccine

Vet Microbiol, 29 (2003), pp. 121-132

[4]

H.L. Klaasen, M. van der Veen, M.J. Molkenboer, D. Sutton A novel tetravalent Leptospira bacterin protects against infection and shedding following challenge in dogs

Vet Rec, 172 (2013), p. 181

J.M. Minke, R. Bey, J.P. Tronel, S. Latour, G. Colombet, J. Yvorel, et al. Onset and duration of protective immunity against clinical disease and renal carriage in dogs provided by a bivalent inactivated leptospirosis vaccine

Vet Microbiol, 137 (2009), pp. 137-145

S. Wilson, C. Stirling, A. Thomas, V. King, E. Plevova, L. Chroma, et al. Duration of immunity of a multivalent (DHPPi/L4R) canine vaccine against four Leptospira serovars

Vaccine, 31 (2013), pp. 3126-3130

C.A. Ganoza, M.A. Matthias, M. Saito, M. Cespedes, E. Gotuzzo, J.M. Vinetz Asymptomatic renal colonization of humans in the peruvian amazon by Leptospira

PLoS Negl Trop Dis (2013), 10.1371/journal.pntd.0000.612

$[8]$

D.J. Houwers, M.G. Goris, T. Abdoel, J.A. Kas, S.S. Knobbe, A.M. van Dongen, et al. Agglutinating antibodies against pathogenic Leptospira in healthy dogs and horses indicate common exposure and regular occurrence of subclinical infections

Vet Microbiol, 148 (2011), pp. 449-451

[9]

E. Scanziani, F. Origgi, A.M. Giusti, G. Iacchia, A. Vasino, G. Pirovano, et al. Serological survey of Leptospiral infection in kennelled dogs in Italy

J Small Anim Pract, 43 (2002), pp. 154-157

J.E. Stokes, J.B. Kaneene, W.D. Schall, J.M. Kruger, R. Miller, L. Kaiser, et al. Prevalence of serum antibodies against six Leptospira serovars in healthy dogs

J Am Vet Med Assoc, 230 (2007), pp. 1657-1664 
N. Gay, M.E. Soupé-Gilbert, C. Goarant Though not reservoirs, dogs might transmit Leptospira in New Caledonia

J Environ Res Public Health, 11 (2014), pp. 4316-4325

K.R. Harkin, Y.M. Roshto, J.T. Sullivan, T.J. Purvis, M.M. Chengappa Comparison of polymerase chain reaction assay, bacteriologic culture, and serologic testing in assessment of prevalence of urinary shedding of leptospires in dogs

J Am Vet Med Assoc, 222 (2003), pp. 1230-1233

[13]

J.R. Llewellyn, I. Krupka-Dyachenko, A.L. Rettinger, V. Dyachenko, I. Stamm, P.A. Kopp, et

$a l$.

Urinary shedding of leptospires and presence of Leptospira antibodies in healthy dogs from upper Bavaria

Bern Munch Tierarztl Wochenschr, 129 (2016)

[251-157]

$[14]$

S.T. Oliveira, J.B. Messick, A.W. Biondo, A.P. dos Santos, R. Stedile, M.L. Dalmolin, et al .Exposure to Leptospira spp. in sick dogs, shelter dogs and dogs from an endemic area: points to consider Acta Sci Vet, 40 (2012), p. 1056

P. Rojas, A.M. Monahan, S. Schuller, I.S. Miller, B.K. Markey, J.E. Nally Detection and quantification of leptospires in urine of dogs: a maintenance host for the zoonotic disease leptospirosis

Eur J Clin Microbiol Infect Dis, 29 (2010), pp. 1305-1309

F. Merien, P. Amouriaux, P. Perolat, G. Baranton, I. Saint Girons Polymerase chain reaction for detection of Leptospira spp. in clinical samples

J Clin Microbiol, 30 (1992), pp. 2219-2224

A.L. Zilber, M. Picardeau, F. Ayral, M. Artois, P. Demont, A. KodjoHigh-resolution $\quad$ typing $\quad$ of Leptospira interrogans strains by multispacer sequence typing

J Clin Microbiol, 52 (2014), pp. 564-571

L. Salaün, F. Merien, S. Gurianova, G. Baranton, M. Picardeau Application of multilocus variablenumber tandem-repeat analysis for molecular typing of the agent of leptospirosis

J Clin Microbiol, 44 (2006), pp. 3954-3962

N. Birnbaum, S.C. Barr, S.A. Center, T. Schermerhorn, J.F. Randolph, K.W. Simpson $\quad$ Naturally acquired leptospirosis in $\mathbf{3 6}$ dogs: serological and clinicopathological features J Small Anim Pract, 39 (1998), pp. 231-236 
L. Azocar-Aedo, G. Monti Meta-Analyses of factors associated with leptospirosis in domestic dogs Zoonoses Public Health, 63 (2016), pp. 328-336

M.P. Ward, L.T. Glickman, L.F. Guptill Prevalence of and risk factors for leptospirosis among dogs in the United States and Canada: 677 cases (1970-1998

J Am Vet Med Assoc, 220 (2002), pp. 53-58

G.S. Ghneim, J.H. Viers, B.B. Chomel, P.H. Kass, D.A. Descollonges, M.L. Johnson Use of a casecontrol study and geographic information systems to determine environmental and demographic risk factors for canine leptospirosis

Vet Res, 38 (2007), pp. 37-50

S. Villumsen, R. Pedersen, M.B. Borre, P. Ahrens, J.S. Jensen, K.A. Krogfelt $\quad$ Novel $\quad$ TaqMan $^{\circledR}$ for detection of Leptospira species in urine and blood: pit-falls in silico validation

J Microbiol Methods, 91 (2012), pp. 184-190

A. Desvars Epidémiologie d'une zoonose, la leptospirose, dans deux îles de l'Océan Indien, la Réunion et Mayotte. Étude comparée du rôle de différentes espèces sauvages et domestiques

Université de la Réunion, Saint Denis (2012)

(PhD Thesis)

R.E. Goldstein Canine leptospirosis

Vet Clin North Am Small Anim Pract, 40 (2010), pp. 1091-1101

V.A. Alves, L.C.C. Gayotto, P.H. Yasuda, A. Wakamatsu, C.T. Kanamura, T. De Brito Leptospiral antigens (L. interrogans serogroup ictero-haemorrhagiae) in the kidney of experimentally infected guinea pigs and their relation to the pathogenesis of the renal injury

Exp Pathol, 42 (1991), pp. 81-93

D.A. Athanazio, E.F. Silva, C.S. Santos, G.M. Rocha, M.A. Vannier-Santos, A.J. McBride, et al. Rattus norvegicus as a model for persistent renal colonization by pathogenic Leptospira interrogans

Acta Trop, 105 (2008), pp. 176-180

C. Branger, B. Blanchard, C. Fillonneau, I. Suard, F. Aviat, B. Chevallier, et al. Polymerase chain reaction assay specific for pathogenic Leptospira based on the gene hap1 encoding the hemolysisassociated protein-1

FEMS Microbiol Lett, 243 (2005), pp. 437-445 
J.N. Midence, C.M. Leutenegger, A.M. Chandler, R.E. Goldstein Effects of recent Leptospira vaccination on whole blood real-time PCR testing in healthy client-owned dogs

J Vet Int Med, 26 (2012), pp. 149-215

Crédits de formation continue. - La lecture de cet article ouvre droit à 0,05 CFC. La déclaration de lecture, individuelle et volontaire, est à effectuer auprès du CNVFCC (cf. sommaire).

Laboratoire des Leptospires, VetAgro Sup, Marcy L'Etoile, France.

BLAST, National center for biotechnology information, National institutes of health, Bethesda, Md. Available at: blast.ncbi.nlm.nih.gov/, (Accessed 09/03/2011). 